\title{
Parasite communities of the Schlei Fjord (Baltic coast of northern Germany)
}

\author{
V. Kesting, S. Gollasch \& C. D. Zander* \\ Zoologisches Institut und Zoologisches Museum der Universität; \\ Martin-Luther-King-Platz 3, D-20146 Hamburg, Germany
}

\begin{abstract}
The parasite faunas of snails, mussels, crustaceans and small-sized fishes were investigated over a period of six months in the Schlei fjord, on the Baltic coast of Schleswig-Holstein. Two sites differing in salinities were compared: Missunde with 5-9\% and Olpenitz with 12-20\%. Prevalences, number of host-parasite combinations, numbers of core and secondary species were generally higher in Olpenitz than in Missunde. In the latter site, only prevalences of cestodans in planktic copepods and the number of rare species were apparent. Specificity of parasites was relatively high in snails, mussels and fishes, but lower in benthic crustaceans. Parasites may survive in an extreme environment like brackish water by means of special strategies which differ from those acquired in the marine milieu: suspension of specificity, adaptation to hosts which are genuine brackish water species, extension of host spectra, and shortening of life-cycles. Although the parasite communities of the Schlei fjord were primarily influenced by the prevailing salinities, the influence of other factors, e.g. environmental stress, was also confirmed. Whereas generally low prevalences in Missunde may contradict Thienemann's biocoenotic rule, planktic parasites infested their hosts often at higher rates than in Olpenitz. This phenomenon is explained by the poorer environmental condition of the benthal zone in Missunde compared to that of the pelagial or the benthal zones of Olpenitz.
\end{abstract}

\section{INTRODUCTION}

The Schlei fjord in northern Schleswig-Holstein has been intensively investigated in regard to the communities of benthos, plankton and nekton (Nellen, 1967; Rheinheimer, 1970; Schriever, 1974; Delling, 1975). The Schlei is a brackish-water area which extends for $42 \mathrm{~km}$ from Schleswig where salinities are $0 \%$ to the influx into the Baltic Sea with $15-18 \%$ (Fig. 1). Additionally, the waters are severely polluted by the waste-products of farming which cause a permanent eutrophication with regular phytoplankton blooms in spring and summer (Rheinheimer, 1970) and large mud deposition on the bottom.

The abiotic factors mentioned give rise to a rich herbivorous and detritivorous fauna which is exploited by several small fish species (Schmidt-Moser \& Westphal, 1981; Antholz et al., 1991; Zander \& Westphal, 1992). The extreme conditions of brackish waters are responsible for a species-poor but individual-rich fauna, especially in the middle part of the Schlei where salinity is only $6-8 \%$. This corresponds to the site of species minimum according to Remane (1958) and follows the law of Thienemann (1939) because low salinities mean extreme abiotic conditions for both marine as well as limnetic organisms.

\footnotetext{
- Addressee for all correspondence
} 


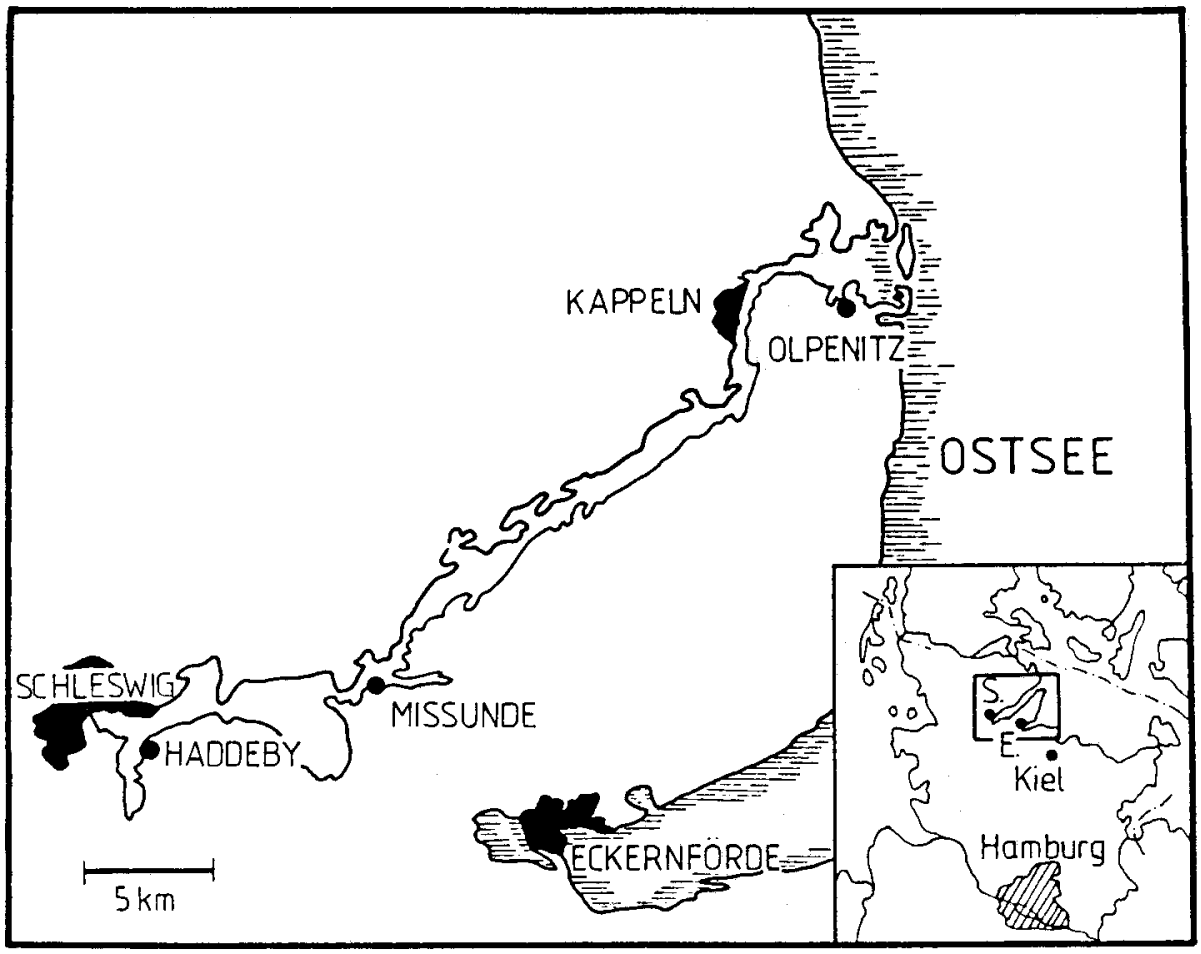

Fig. 1. Map of Schleswig-Holstein (inset) and of the Schlei fjord (enlarged) presenting the sampling sites of Missunde and Olpenitz. Ostsee = Baltic Sea. From Zander \& Westphal (1991)

Recent parasitological investigations in the Schlei fjord concentrated on single parasites in regard to their prevalences and life-cycles (Zander et al., 1984; Kreft, 1991), or on species compositions in single host groups (Wendland, 1985; Zander \& Westphal, 1991; Gollasch, 1992; Kesting, 1992; Gollasch \& Zander, 1995). The present study undertakes a synthesis of parasite communities of several host groups with the aim of analysing the compound community of this area in the sense of Esch et al. (1990). The question as to how different salinities such as those encountered in the Schlei fjord influence the species composition and prevalence of the respective parasite communities was of special interest. For the analysis the groups of snails, mussels, crustaceans and fishes were considered. These are primary, secondary or final hosts and, additionally, represent groups of different mobility. Another aim of this study was to elaborate the main hosts within the cycles of helminth parasites. It may be assumed that in extreme habitats like brackish waters other hosts are preferred than are preferred in the marine milieu.

\section{SAMPLING SITES, MATERIAL AND METHODS}

Samples were taken at two sites of the Schlei fjord which clearly differ in their prevailing salinities. "Missunde" is located at the influx of the "Ornumer Noor" into the "Missunde Enge" (Fig. 1), presenting salinities of 5-9\%. "Olpenitz" lies at the southern 
Table 1. Compilation of host species from the Schlei fjord

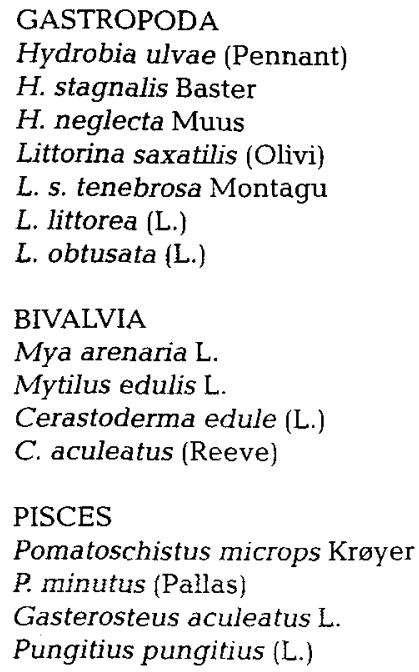

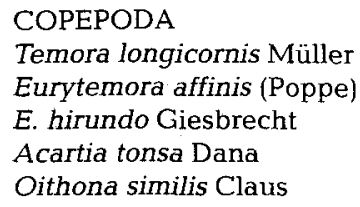

edge of the "Olpenitzer Noor" and attains salinities of 12-20\%.

The samples were taken every four weeks from April to September 1991 and combined plankton, benthos, fishes and, additionally, phyton in Olpenitz. Plankton was extracted from $100 \mathrm{l}$ water which was poured through a net of $55 \mu \mathrm{m}$ meshsize. Most of the benthos and all fishes were sampled by means of large hand nets with 2-5 mm meshsize which were drawn fast over the bottom. Snails were extracted from the bottom by means of a corer with an opening of $10 \mathrm{~cm}^{2}$. Phytal fauna was obtained only in Olpenitz, by loosening Fucus vesiculosus thalli from the substrate, and transferred under water into a 101 PVC box. Snails and phytal fauna were transported alive to the laboratory; benthos and plankton were fixed in $70 \%$ ethanol, fishes in $4 \%$ Formalin.

All potential hosts were determined to the species level and carefully examined by means of a stereomicroscope in order to find parasites. The most important hosts are compiled in Table 1. Parasites were separated from their hosts and treated with lactic acid in order to clear organs for determination.

The following parameter and index were used. Prevalence = part of a host population which was infested by a specific parasite. In most cases, the mean prevalence was calculated from the prevalences of the six samples collected during the investigation period. Only in four selected digeneans, which were conspicuously abundant in two or three different hosts, were the monthly prevalences presented separately. In order to evaluate the importance of the infestation rates the core-satellite concept of Holmes \& Price (1986) was used: core species $=$ prevalence $>60 \%$; secondary species $=40-60 \%$; satellite spe- 


\begin{tabular}{|c|c|c|c|c|c|c|c|}
\hline & $\begin{array}{l}\text { Snails, } \\
1 \text {. int. } \\
\text { host }\end{array}$ & $\begin{array}{c}\text { Snails, } \\
\text { 2. int. } \\
\text { host }\end{array}$ & Mussels & $\begin{array}{l}\text { Plankto- } \\
\text { nic crus- } \\
\text { taceans }\end{array}$ & $\begin{array}{l}\text { Benthic } \\
\text { crusta- } \\
\text { ceans }\end{array}$ & Fishes & Birds \\
\hline \multicolumn{8}{|l|}{ DIGENEA } \\
\hline Podocotyle atomon & 0 & & & & 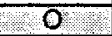 & . & \\
\hline Asymphyllodora demeli & 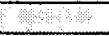 & & 0 & & & 12 & \\
\hline Himasthla interrupta & 10. & & O & & & & 06 \\
\hline Microphallus claviformis & $O M \#$ & 9 & & & $O M$ & IHIII & (3) \\
\hline M. papillorobustum & 0 & & & & $\mathrm{OM}$ & & 6 \\
\hline Maritrema subdolum & 0 & 8 & & & $\mathrm{OM}$ & & of \\
\hline Cercaria microphallidarum no. 4 & 0 & & & & & & \\
\hline Diplostomum spathaceum & & & & & & M & $2 .+1 / 2$ \\
\hline Cryptocotyle concavum & $O M \#$ & & & & & $.0 M$ & $\mathrm{Ob}^{2}$ \\
\hline C. lingua & O\# & & & & & $0^{1}$ & 904 \\
\hline Brachyphallus crenatus & O\# & & & ?७? & & \%(Y) & \\
\hline Hemiurus communis & & & & 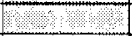 & & (5) & \\
\hline Magnibursatus caudofilamentosa & & & & & $2=$ & $\sigma_{0}$ & \\
\hline Psilochasmus oxyurus & 0 & OM\# & & & & & 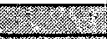 \\
\hline Psilostomum brevicolle & & एक?!? & 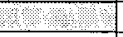 & & & & Ot: \\
\hline Acanthostomum imbutiforme & & & & & & 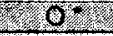 & \\
\hline Mesorchis denticulatus & $M^{*}$ & & & & & 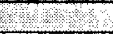 & Q6 \\
\hline Cercaria ephemera & $\mathrm{O}^{*} \mathrm{M}^{*}$ & & & & & & $\sqrt{2}$ \\
\hline \multicolumn{8}{|l|}{ TURBELLARIA } \\
\hline Paravortex cardii & & & OWW & & & & \\
\hline \multicolumn{8}{|l|}{ Explanations: } \\
\hline$M=$ Missunde & & & & \multirow{2}{*}{\multicolumn{2}{|c|}{ 1. intermediate host }} & & \\
\hline $\mathrm{O}=$ Olpenitz & & & & & & & \\
\hline $\mathrm{Oe}=$ Oehe-Schleimünde & & & & \multicolumn{2}{|c|}{ 3. intermediate host } & & \\
\hline * KREFT (1991); \# WENDLAND (19 & & & & Final host & & & \\
\hline
\end{tabular}

Fig. 2. Compilation of digenean and turbellarian parasite life-cycles and their presence at different host leveis. The respective evidence was gained by former and present investigations in the Schlei fjord and is marked accordingly

cies $=5-40 \%$; rare species $=$ prevalence $<5 \%$. The specificity index (SI, Rohde, 1982) was calculated as:

$$
S I=\sum \frac{x(i, j)}{n(j) h(i, j)}+\sum \frac{x(i, j)}{n(j)}
$$

where $x(i, j)=$ number of parasite specimen of species $i$ in host species $j ; n(j)=$ number of host specimen of species $j ; h(i, j)=$ range of host species $j$ infested by parasite $i$.

\section{RESULTS}

\section{Prevalences and cycles}

In total, 33 diverse parasites representing eight taxonomic classes were found during present and former studies in the Schlei fjord (Figs 2, 3) (Wendland, 1985; Kreft, 1991; Zander \& Westphal, 1991). The most important group were digeneans, comprising as many as 18 species (Fig. 2), followed by acanthocephalans with 5 species (Fig. 3). The mentioned studies, when combined, were able to pursue complete life-cycles of six digeneans, but the development of Podocotyle atomon was the only complete one in the 


\begin{tabular}{|c|c|c|c|c|c|c|c|}
\hline & $\begin{array}{c}\text { Plankto- } \\
\text { nic cru- } \\
\text { staceans }\end{array}$ & $\begin{array}{l}\text { Benthic } \\
\text { crusta- } \\
\text { ceans }\end{array}$ & Mussels & $\begin{array}{l}\text { Fishes } \\
\text { (interm. } \\
\text { hosts) }\end{array}$ & $\begin{array}{c}\text { Fishes } \\
\text { (final } \\
\text { hosts) }\end{array}$ & Seais & Birds \\
\hline \multicolumn{8}{|l|}{ CESTODA } \\
\hline Hymenolepis sp. & & $M$ & & & & & \\
\hline Schistocephalus sp. & O? M? & & & $O M$ & & & \\
\hline Proteocephalus percae & $\mathrm{O} ? \mathrm{M}$ ? & & & $O \mathrm{OM}$ & 12 & & \\
\hline \multicolumn{8}{|l|}{ NEMATODA } \\
\hline Pseudanisakis truncata & & $\mathrm{M}$ & & & 5.2 & & \\
\hline Hysterothylacium sp. & & $O M$ & 0. & $0 \mathrm{M}$ & 2.2 & & \\
\hline \multicolumn{8}{|l|}{ ACANTHOCEPHALA } \\
\hline Polymorphus botulus & & $O M$ & & & & & \\
\hline Acanthocephalus sp. & & 0 & & & & & \\
\hline Corynosoma sp. & & & & 0 & & & \\
\hline Pomphorhynchus laevis & & & & & M. & & \\
\hline Neoechinorhynchus rutili & & & & & $\mathrm{M}$ & & \\
\hline \multicolumn{8}{|l|}{ COPEPODA } \\
\hline Thersitina gasterostei & & & & & OM & & \\
\hline Caligus lacustris & & & & & $\mathrm{M}$ & & \\
\hline \multicolumn{8}{|l|}{ MICROSPORIDIA } \\
\hline Glugea anomala & & & & $O M$ & $O M$ & & \\
\hline \multicolumn{8}{|l|}{ MYXOSPORIDIA } \\
\hline Henneguya sp. & & & & $\mathrm{O}^{*} \mathrm{M}^{\star}$ & & & \\
\hline \multicolumn{8}{|l|}{ Explanations: } \\
\hline $\mathrm{M}=$ Missunde & & & & 1. interme & diate host & & \\
\hline $\bar{O}=$ Olpenitz & & & & 2. interme & diate host & & \\
\hline “ ZANDER \& WESTPHAL & 1991) & & 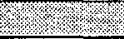 & Final host & & & \\
\hline
\end{tabular}

Fig. 3. Compilation of parasite life cycles of diverse groups and their presence at different host levels. The respective evidence gained by earlier and present investigations in the Schlei fjord is marked accordingly

present study. The description of infestation follows the five different host groups: snails, mussels, planktic and benthic crustaceans, and fishes (Figs 4-8).

The snails were represented by Littorina spp. in Olpenitz and Hydrobia spp. in Olpenitz as well as in Missunde. Infestation by digeneans was found only in Olpenitz (Fig. 4). Highest prevalences (more than $20 \%$ ) were caused by the microphallids Microphallus claviformis and Maritrema subdolum in Hydrobia spp. Lower values were attained by Podocotyle atomon and Psilochasmus oxyurus in Littorina spp.; Cryptocotyle concavum and the other three parasites were of lesser importance (Fig. 4). Some Hydrobia specimens harboured not only cercariae but also metacercariae of $M$. claviformis and $M$. subdolum which indicate their role as 1 . as well as 2 . intermediate host.

Four mussel species were investigated, but only Cerastoderma edule was present in Olpenitz as well as in Missunde and infested by the turbellarian Paravortex cardii (Fig. 5). The digenean Himasthla interrupta which attained prevalences of 1-6\% was the most important parasite of mussels, whereas Asymphyllodora demeli played a less conspicuous role (Fig. 5). 


\begin{tabular}{|c|c|c|c|c|c|c|c|c|c|}
\hline$I \stackrel{\mathbb{J}}{\sigma} \bar{\Sigma}$ & $\cong$ & & & & & & & & \\
\hline 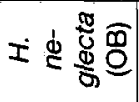 & -5 & & & & & 10 & & & \\
\hline 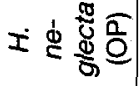 & $\neq$ & & & & & 跑 & & & 2 \\
\hline 工蔫昜 & 우 & & & & & & & & \\
\hline 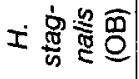 & $\stackrel{\mathscr{g}}{\square}$ & & & - & 5 & $\circ$ & m. & $v$. & \\
\hline 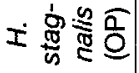 & 品 & & & & $\nabla$ & $\bar{N}$ & & 12 & ก) \\
\hline I胥 & $\hat{\oplus}$ & & & & & & & & \\
\hline 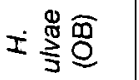 & $\mid$ & & & & & m) & & & \\
\hline 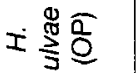 & \begin{tabular}{|l}
$\infty$ \\
$\infty$
\end{tabular} & & & & : & $\ddot{\circ}$ & & & \\
\hline 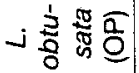 & $\infty$ & & 0 & & & & & & \\
\hline ن & $\stackrel{\sim}{2}$ & $=$ & $\approx$ & & & & & & \\
\hline ن & 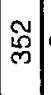 & & $\sigma$ & & & & & & \\
\hline 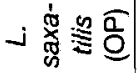 & if & $\sim$ & $\stackrel{\infty}{=}$ & & & & & & \\
\hline 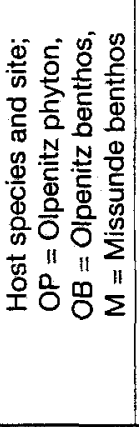 & $z$ & 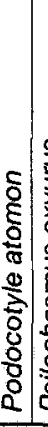 & 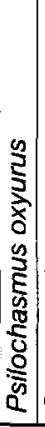 & 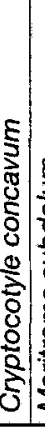 & 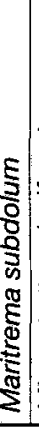 & 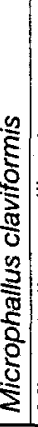 & 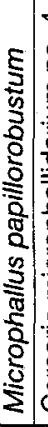 & 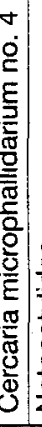 & 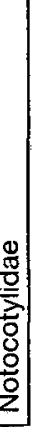 \\
\hline
\end{tabular}



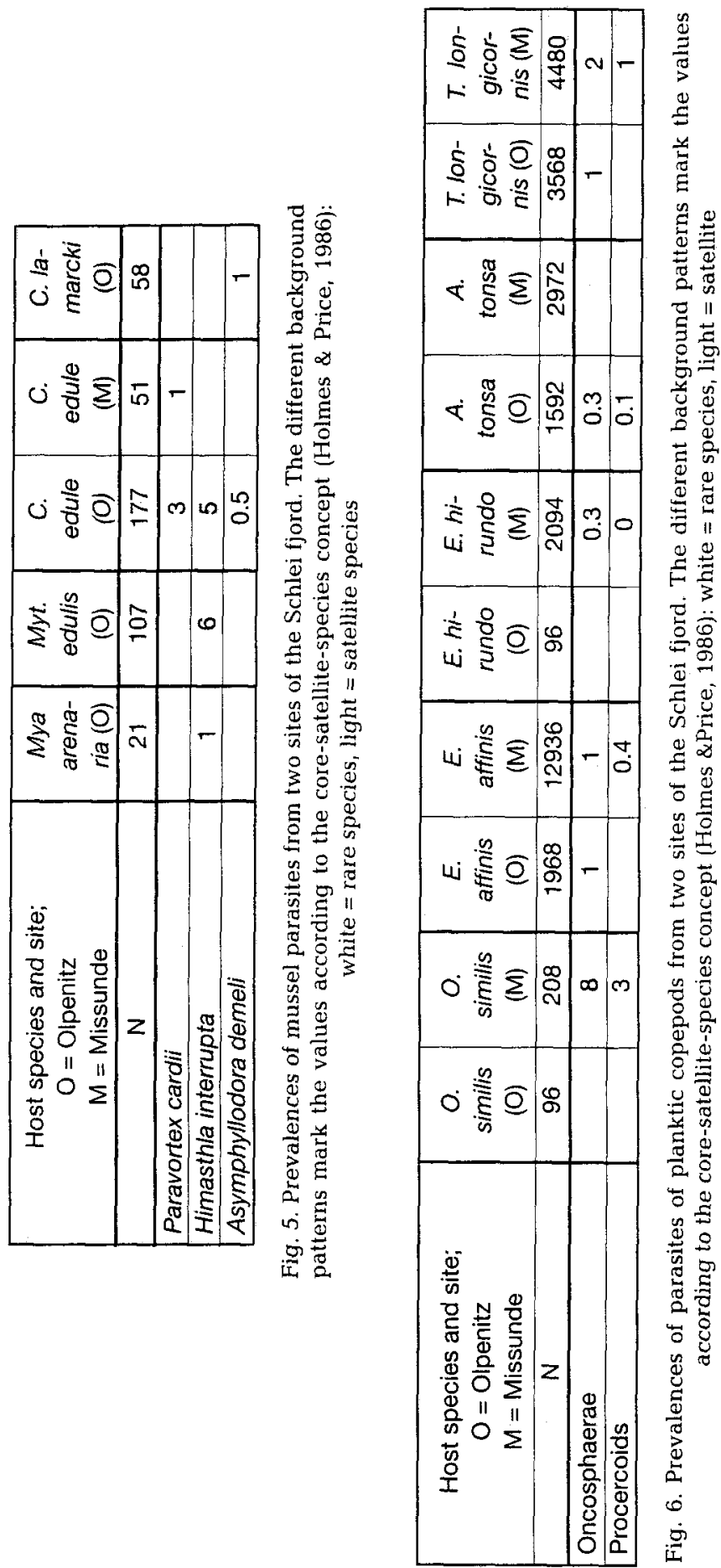


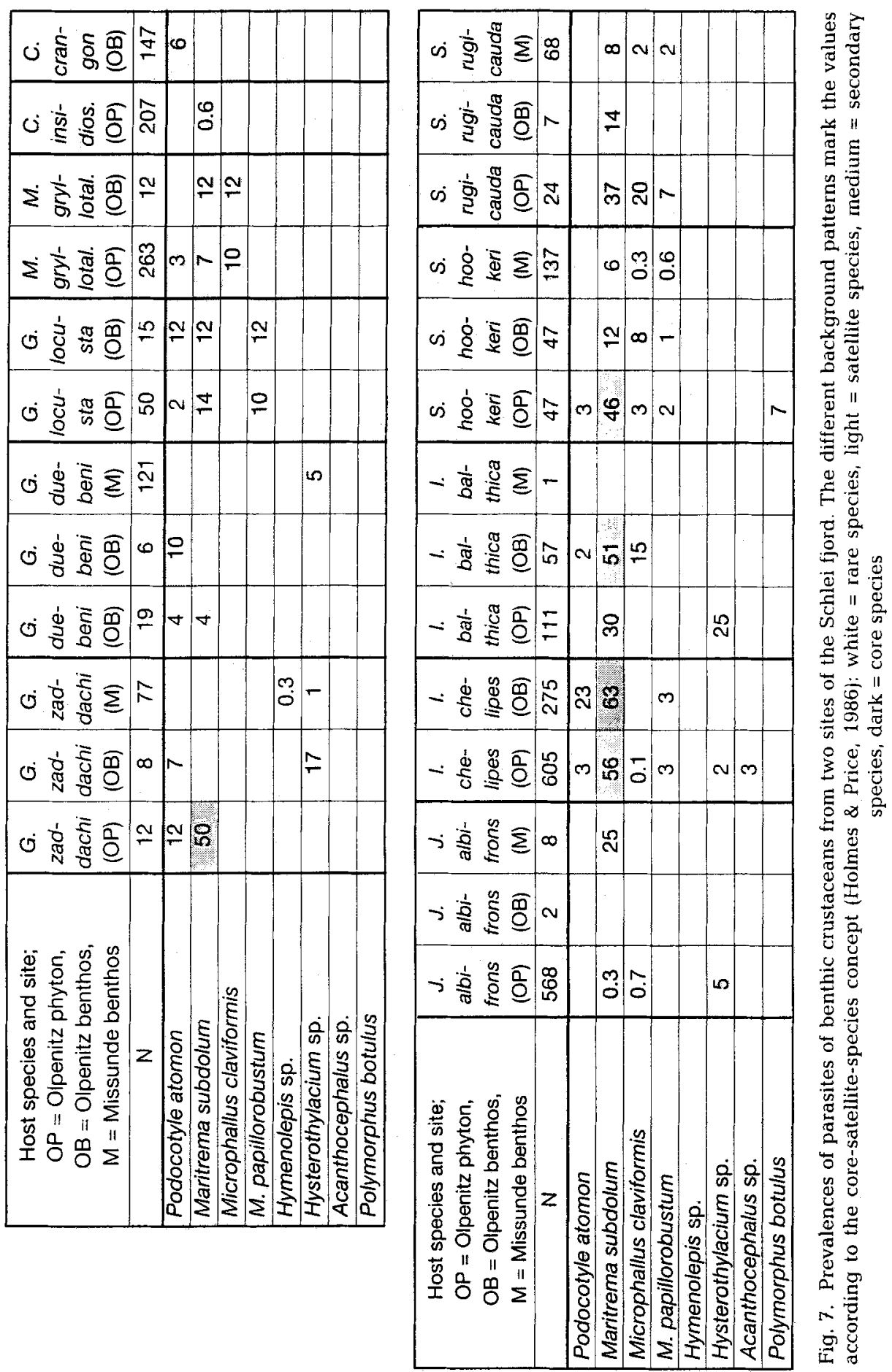




\begin{tabular}{|c|c|c|c|c|c|c|c|c|}
\hline $\begin{array}{l}\text { Host species and site; } \\
\qquad \begin{array}{c}M=\text { Missunde } \\
O=\text { Olpenitz }\end{array}\end{array}$ & $\begin{array}{c}P . \\
\text { mi- } \\
\text { crops } \\
(\mathrm{M})\end{array}$ & $\begin{array}{c}P . \\
\text { mi- } \\
\text { crops } \\
(\mathrm{O})\end{array}$ & $\begin{array}{c}P . \\
\text { mi- } \\
\text { nutus } \\
(\mathrm{M})\end{array}$ & $\begin{array}{c}P . \\
\text { mi- } \\
\text { nutus } \\
(\mathrm{O})\end{array}$ & $\begin{array}{c}\text { G. } \\
\text { acu- } \\
\text { leatus } \\
\text { (M) }\end{array}$ & $\begin{array}{c}\text { G. } \\
\text { acu- } \\
\text { leatus } \\
(0)\end{array}$ & $\begin{array}{c}P . \\
\text { pun- } \\
\text { gitius } \\
(\mathrm{M})\end{array}$ & $\begin{array}{c}P . \\
\text { pun- } \\
\text { gitius } \\
(\mathrm{O})\end{array}$ \\
\hline $\mathrm{N}$ & 101 & 194 & 72 & 2 & 33 & 40 & 1 & 57 \\
\hline Podocotyle atomon & 2 & 41 & & 120 & 2 & 52 & & 40 \\
\hline Brachyphallus crenatus & & & & & 6 & 2 & & \\
\hline Hemiurus communis & & & & & & 11 & & 8 \\
\hline Diplostomum spathaceum & 0.4 & & & & & & & \\
\hline Cryptocotyle concavum (kidney cysts) & 10 & 83 & & 101 & & & & \\
\hline Cryptocotyle concavum (dermal cysts) & 2 & 15 & 1 & & 2 & 51 & & 35 \\
\hline Magnibursatus caudofilamentosa & & & & & & 14 & & \\
\hline Proteocephalus percae & 8 & 0.3 & & & & & & \\
\hline Schistocephalus sp. & 2 & 1 & 0.6 & & & & & \\
\hline Hysterothylacium sp. & 2 & 1 & & & 3 & & & 5 \\
\hline Corynosoma sp. & & 12 & 3 & & & & & 4 \\
\hline Pomphorhynchus laevis & & & & & 8 & & & \\
\hline Thersitina gasterostei & & & & & 19 & 64 & 106 & 16 \\
\hline Glugea sp. & & & & & 3 & 5 & & \\
\hline
\end{tabular}

Fig. 8. Prevalences of parasites of small-sized fishes from two sites of the Schlei fjord. The different background patterns mark the values according to the core-satellite-species concept (Holmes \& Price, 1986): white = rare species, light $=$ satellite species, medium $=$ secondary species, dark $=$ core species

Planktic hosts comprised four calanoid and one cyclopoid copepod species which were infested in Olpenitz as well as in Missunde (Fig. 6). They were parasitized by early developmental stages of cestodans which were not determinable. Probably, they were larvae of Schistocephalus sp. and/or Proteocephalus percae which were found in fishes, their 2. intermediate hosts (Fig. 8). It was conspicuous that prevalences of copepods seemed to be higher in Missunde than in Olpenitz (Fig. 6).

Benthic crustaceans comprised 11 species and, therefore, were the largest host group (Fig. 7). They were 1. or 2. intermediate hosts of several helminths. Microphallid digeneans, especially Maritrema subdolum, attained the highest prevalences (63\% max.) in as many as 10 hosts in Olpenitz and three in Missunde. Idotea chelipes which harboured 6 parasites, and Sphaeroma hookeri with 5 parasites were further important hosts (Fig. 7). Gammarus spp. were not only infested by the bird parasites Microphallidae but also in high prevalences by Podocotyle atomon which lives in fishes as final hosts. Remarkably, Crangon crangon harboured this parasite, too. Not only microphallids were found in Missunde but also the less specialized nematode Hysterothylacium as well as the cestodan Hymenolepis which was only found in Gammarus zaddachi (Fig. 7).

The host group fishes comprised two gobies and two sticklebacks. They harboured as many as six digeneans and seven other parasites (Fig. 8). The highest prevalences were attained by Cryptocotyle concavum, Thersitina gasterostei and Podocotyle atomon at the Olpenitz site. Thersitina gasterostei, C. concavum, Proteocephallus percae and Pomphorhynchus laevis dominated in Missunde where clearly lower prevalences than in Olpenitz prevailed. $C$. concavum appeared as metacercariae cysts in the kidneys of gobies or in the skin of gobies as well as sticklebacks. The intensities of cysts clearly 


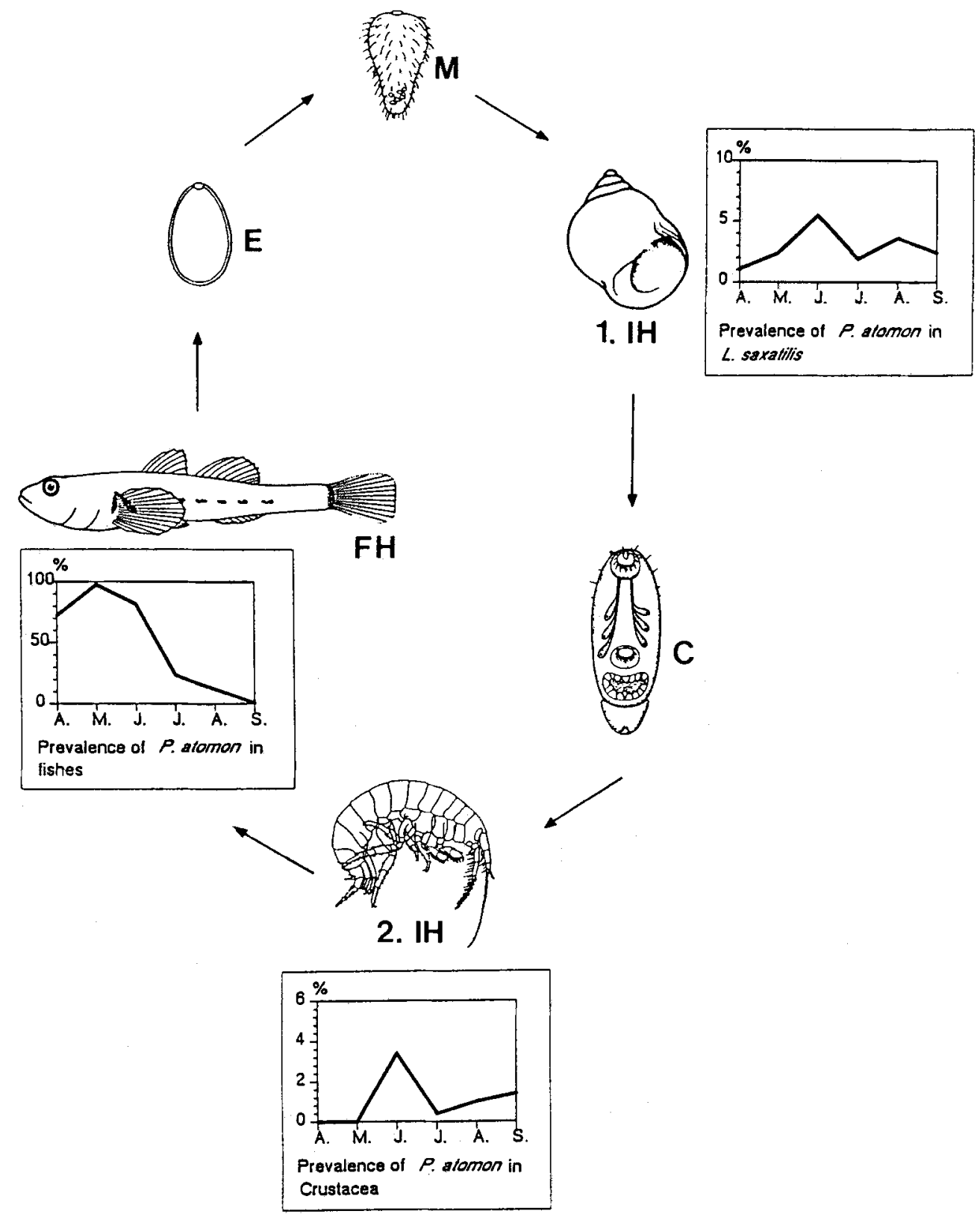

Fig. 9. Life-cycle of Podocotyle atomon presenting monthly prevalences in Olpenitz over six months at all three host levels. Explanations: $\mathrm{C}=$ cercaria, $\mathrm{E}=\mathrm{egg}, \mathrm{FH}=$ final host, $\mathrm{IH}=$ intermediate host, $\mathrm{M}=$ miracidium 


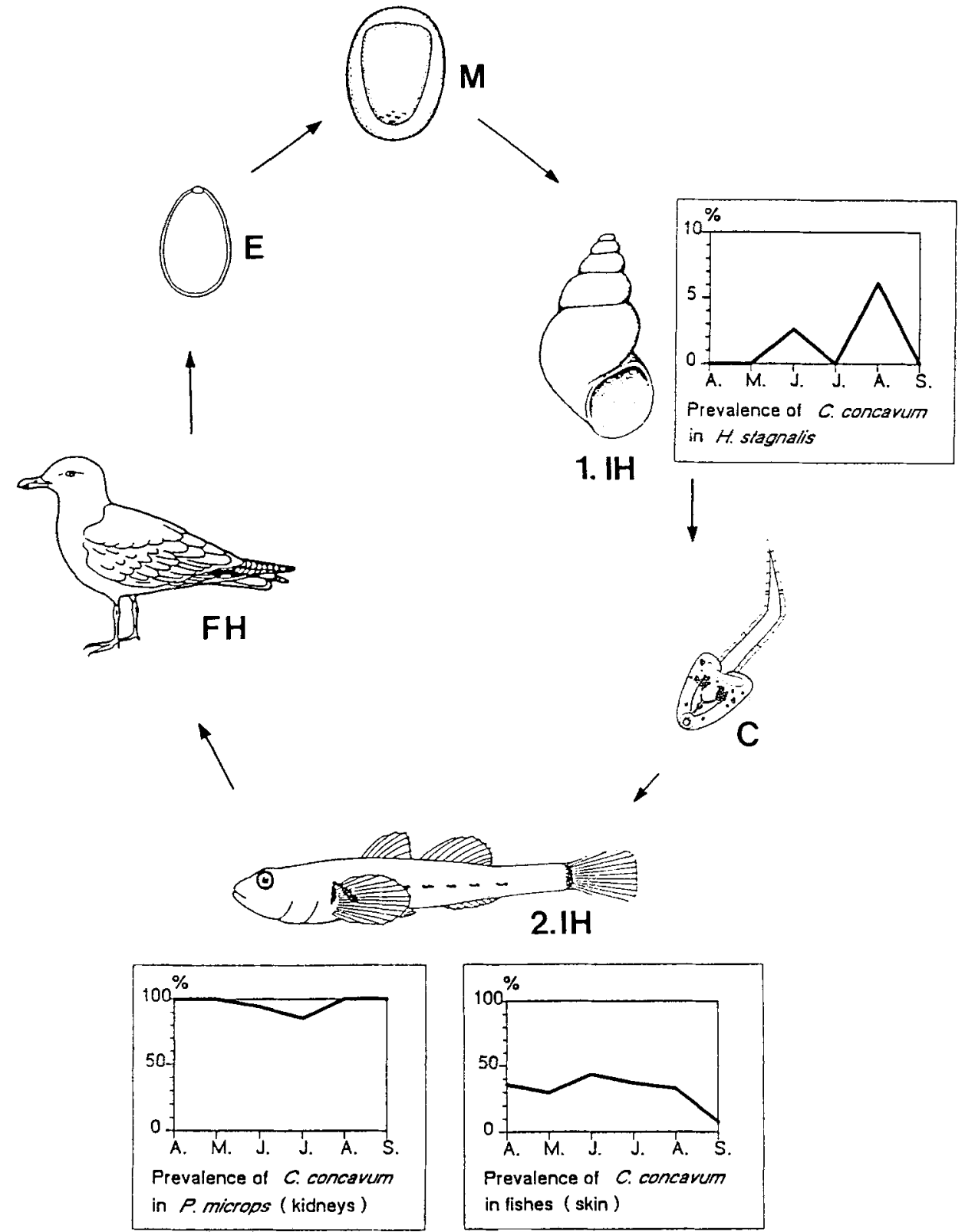

Fig. 10. Life-cycle of Cryptocotyle concavum presenting monthly prevalences in Olpenitz over six months at two host levels. Explanations see Fig. 9. 


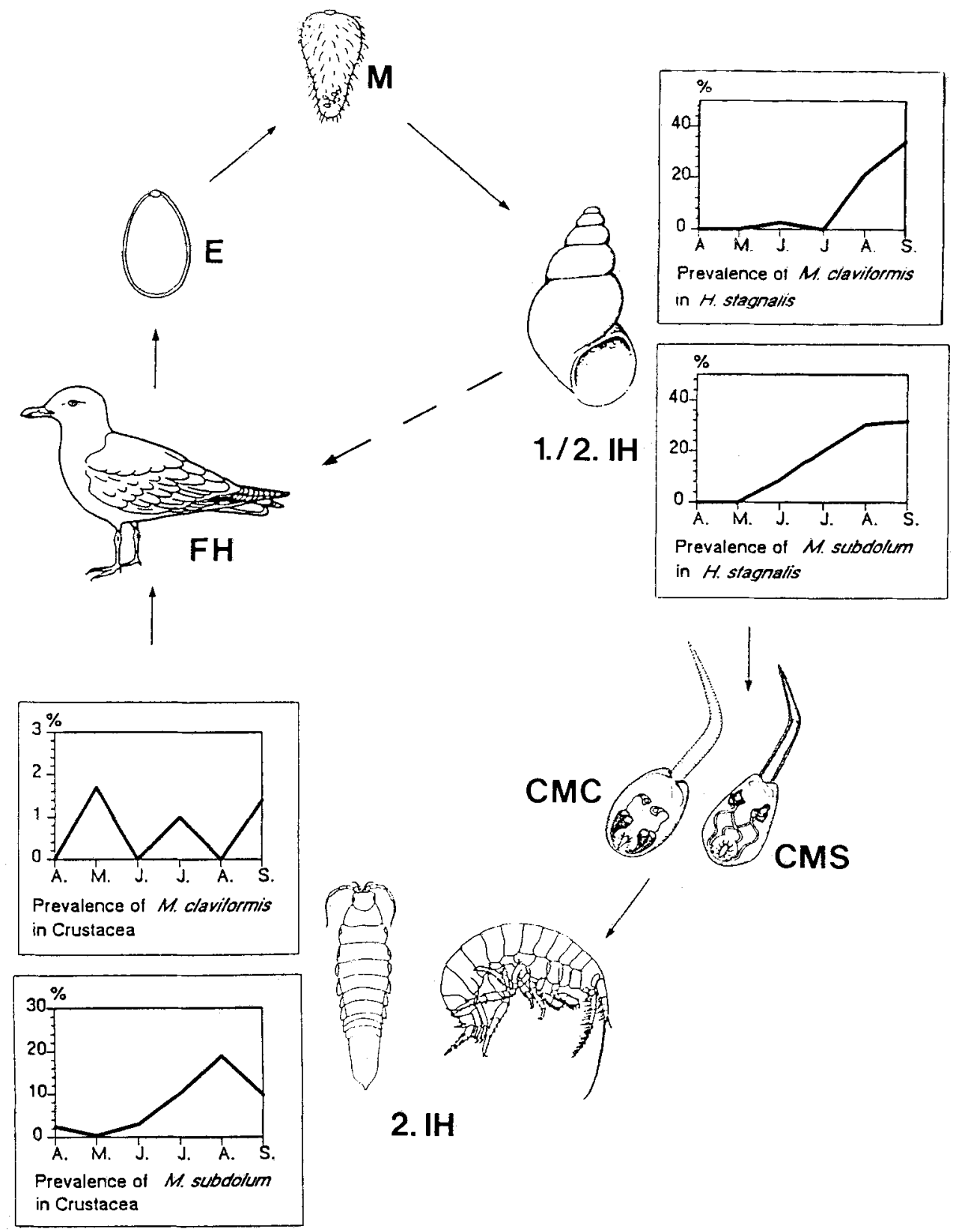

Fig. 11. Life-cycles of Micropnallus claviformis and Maritrema subdolum presenting monthly prevalences in Olpenitz over six months at two host levels. For explanations see Fig. 9 and, additionally: $\mathrm{CMC}=$ cercaria of Microphallus claviformis, CMS = cercaria of Maritrema subdolum. 


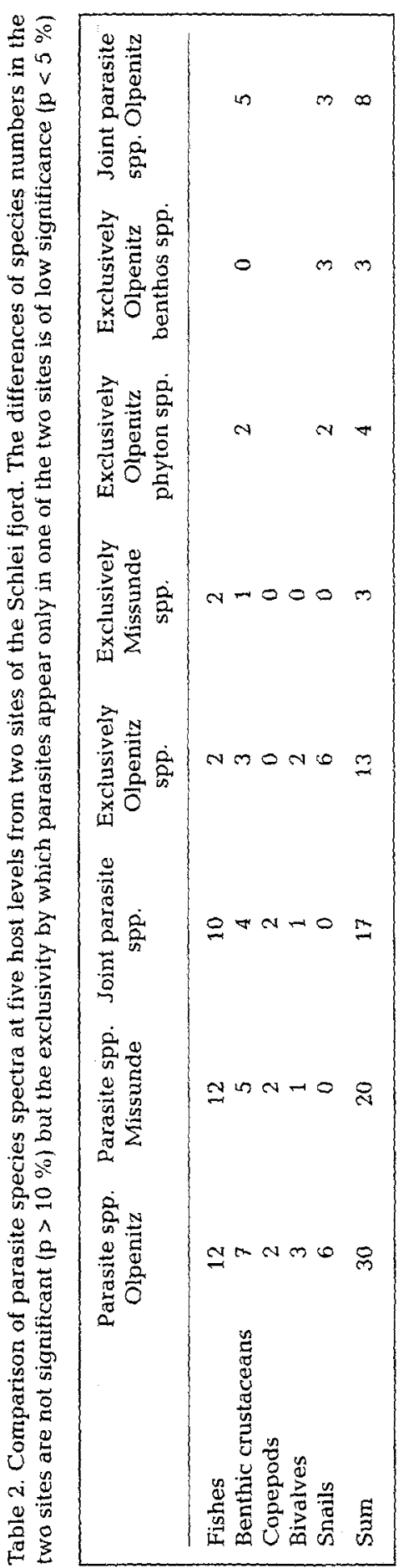


Table 3. Comparison of parasite prevalences at two sites of the Schlei fjord. The higher prevalences in Olpenitz are significant $(\mathrm{p}<1 \%)$

\begin{tabular}{|lcccc|}
\hline & $\begin{array}{c}\text { Joint host- } \\
\text { parasite } \\
\text { combination }\end{array}$ & $\begin{array}{c}\text { Equal } \\
\text { prevalences }\end{array}$ & $\begin{array}{c}\text { Prevalence } \\
\text { higher in } \\
\text { Olpenitz }\end{array}$ & $\begin{array}{c}\text { Prevalence } \\
\text { higher in } \\
\text { Missunde }\end{array}$ \\
\hline Fishes & 11 & 2 & 7 & 2 \\
Benthic crustaceans & 8 & 1 & 6 & 1 \\
Copepods & 2 & 2 & 1 & 3 \\
Mussels & 1 & & 14 & \\
Snails & 0 & 5 & & \\
\multicolumn{1}{c}{ Sum } & 22 & & & \\
\hline
\end{tabular}

differed in these two microhabitats: In P. microps as many as 2000 kidney cysts were found in a specimen, whereas maximally 17 dermal cysts were found in Gasterosteus aculeatus. Adult flukes of $P$. atomon were found in the middle or hind part of the intestine with maximally 100 specimens. Remarkably, Diplostomum spathaceum appeared exclusively in Missunde, whereas Brachyphallus crenatus and Proteocephalus percae attained larger prevalences in this site than in Olpenitz (Fig. 8).

Some of the most abundant digeneans could be analysed regarding their fluctuations in diverse hosts during the course of half a year. $P$. atomon was found in Littorina saxatilis (1. intermediate host), benthic crustaceans (2. intermediate hosts) and fishes (final hosts) (Fig. 9). The prevalences of this parasite peaked in Littorina and benthic crustaceans in June as well as in August/September. Nearly all fishes were infested in May; thereafter prevalence decreased to zero by September.

Cryptocotyle concavum attained peaks in Hydrobia stagnalis (1. intermediate host) in June and a still larger one in August (Fig. 10). All Pomatoschistus microps, the main 2 . intermediate host, were infested during the whole year by kidney cysts with the exception of July when prevalences lay below $100 \%$. Dermal cysts were less frequent but attained similar values in all four fish hosts during April to August, becoming rarer in September (Fig. 10). Prevalences of the microphallids Maritrema subdolum and Microphallus claviformis were extremely high in their 1. intermediate host Hydrobia stagnalis with more than $30 \%$ in late summer (Fig. 11). The increase of infestation began earlier (July) in $M$. subdolum than in $M$. claviformis which peaked in August in the 2. intermediate hosts, benthic crustaceans. In comparison with $M$. subdolum, the prevalences attained by $M$. claviformis in benthic crustaceans were very low and fluctuated during the half year (Fig. 11).

\section{Analysis of sites and communities}

The differences between the parasite faunas of Olpenitz ( 30 species) and Missunde (20 species) were not extremely great because 17 parasites were present at both sites (Table 2). Subsequently, only 3 (Diplostomum spathaceum on Pomatoschistus microps, Pomphorhynchus laevis on Gasterosteus aculeatus, Hymenolepis sp. on Gammarus zaddachi) were exclusively present in Missunde at low salinities, whereas 13 combinations were characteristic for Olpenitz. 
Table 4. Comparison of the dominances of parasite-host combinations at two sites of the Schlei fjord according to the core-satellite-concept (Holmes \& Price, 1986). The differences between the sites are highly significant $(\mathrm{p}<0.1 \%)$

\begin{tabular}{|c|c|c|c|c|c|c|c|c|c|c|}
\hline \multirow[b]{2}{*}{ Olpenitz/Missunde } & \multicolumn{2}{|c|}{$\begin{array}{l}\text { Core } \\
\text { species }\end{array}$} & \multicolumn{2}{|c|}{$\begin{array}{l}\text { Secondary } \\
\text { species }\end{array}$} & \multicolumn{2}{|c|}{$\begin{array}{l}\text { Satellite } \\
\text { species }\end{array}$} & \multicolumn{2}{|c|}{$\begin{array}{l}\text { Rare } \\
\text { species }\end{array}$} & \multicolumn{2}{|c|}{$\begin{array}{l}\text { Host-parasite } \\
\text { combinations }\end{array}$} \\
\hline & $\mathrm{O}$ & M & $\mathrm{O}$ & $\mathrm{M}$ & $\mathrm{O}$ & $\mathrm{M}$ & $\mathrm{O}$ & $\mathrm{M}$ & $\mathrm{O}$ & $\mathrm{M}$ \\
\hline Fishes & 2 & 0 & 4 & 0 & 9 & 5 & 5 & 12 & 20 & 17 \\
\hline Benthic crustaceans & 1 & 0 & 3 & 0 & 17 & 4 & 12 & 6 & 33 & 10 \\
\hline Copepods & 0 & 0 & 0 & 0 & 0 & 1 & 3 & 3 & 3 & 4 \\
\hline Mussels & 0 & 0 & 0 & 0 & 2 & 0 & 4 & 1 & 6 & 1 \\
\hline Snails & 0 & 0 & 0 & 0 & 8 & 0 & 10 & 0 & 18 & 0 \\
\hline Sum & 3 & 0 & 7 & 0 & 36 & 10 & 34 & 22 & 80 & 32 \\
\hline
\end{tabular}

Parasites from Olpenitz phyton which were not found in the benthos were rare species such as Acanthocephalus sp. in Idotea chelipes and Polymorphus botulus in Sphaeroma hookeri, or first host specialists such as Podocotyle atomon and Psilochasmus oxyurus in Littorina spp.. This group of first host specialists is also decisive for 3 digeneans present in Hydrobia spp. from the benthos only (Table 2).

A comparison of prevalences of parasites in the two sites may reveal further differences (Table 3). Fourteen out of 22 joint host-parasite combinations attained higher values in Olpenitz but only three were of higher prevalences in Missunde: Proteocephalus percae/Pomatoschistus microps, Brachyphallus crenatus/Gasterosteus aculeatus, Maritrema subdolum/Jaera albifrons. Five combinations were considered to be similar in the two sites: cestode larvae in copepods, Hysterothylacium sp. and Schistocephalus sp. in Pomatoschistus microps and Microphallus papillorobustum in Sphaeroma hookeri.

Totally, 80 parasite-host combinations were found in Olpenitz but only 32 in Missunde (Table 4). Three of them were core species of more than $60 \%$ prevalence which occurred only in Olpenitz: Cryptocotyle concavum (kidney cysts)/Pomatoschistus microps, Thersitina gasterostei/Gasterosteus aculeatus and Maritrema subdolum/ Idothea chelipes. Also secondary species with 40-60\% prevalence were not present in Missunde but occurred in 7 combinations from Olpenitz: Podocotyle atomon in Pomatoschistus microps, Gasterosteus aculeatus and Pungitius pungitius; Cryptocotyle concavum (dermal cysts) in Gasterosteus aculeatus; Maritrema subdolum in Gammarus zaddachi, Idothea balthica and Sphaeroma hookeri. Despite generally low prevalences in Missunde some of the 10 satellite species of this site are worth mentioning: these were fish-infesting parasites which represent core species in Olpenitz. Contrarily, the main hosts of Maritrema subdolum changed in Missunde: Jaera albifrons, Sphaeroma hookeri and $S$. rugicauda, the latter being a secondary species in Olpenitz.

The specificity index (Rohde, 1982) revealed parasite specialists, especially in snails and fishes, as well as generalists, especially in benthic crustaceans (Table 5). The only exception regarding snail parasites is Maritrema subdolum which attained a low index of 0.86 . All Digenea and Hysterothylacium sp. attained values of below 0.84 in benthic crustaceans; Maritrema subdolum again presented the minimum (0.68). Only Cestoda and Acanthocephala attained indices of 1 because they were present in only one host species 
Table 5. Specificity indices (Rohde, 1982) regarding parasite prevalences in single hosts and host communities [S (comm.)]

\begin{tabular}{|lcccccccc|}
\hline \multicolumn{1}{c}{ S (prev.) } & $<0.71$ & $0.71-0.80$ & $0.81-0.90$ & $0.91-0.95$ & $0.96-1.00$ & $\mathrm{~N}$ & $\mathrm{~S}$ (comm.) \\
\hline Fishes & 1 & & 4 & 2 & 6 & 13 & 0.93 \\
Benthic crustaceans & 1 & 2 & 2 & & 3 & 8 & 0.86 \\
Plankton & & & & 1 & & 1 & 0.91 \\
Mussels & & & 1 & 2 & & 3 & 0.93 \\
Snails & & & 2 & 2 & 4 & 8 & 0.95 \\
$\quad$ Sum & 2 & 2 & 9 & 7 & 13 & 33 & 0.92 \\
\hline
\end{tabular}

with low prevalences. The fish parasites partially were specialists like Cryptocotyle concavum (kidney cysts) or, to a lesser degree, Thersitina gasterostei and Schistocephalus $\mathrm{sp}$. Generalists were Podocotyle atomon (index $=0.69$ ), Cryptocotyle concavum (dermal cysts $;=0.84)$ and Hysterothylacium sp. $(=0.84)$. The benthic crustaceans presented the lowest specificity; the snails attained the highest values of the 5 host groups (Table 5 ).

\section{DISCUSSION}

Host-parasite relationship in the brackish environment

Parasitism is characterized by the peculiarity that the existence of parasites does not depend on the direct environmental effects only but also on those effects which limit the distribution of their hosts. The compound communities (Esch et al., 1975) investigated in the Schlei fjord were especially rich in hosts that are called genuine brackish-water species, e.g. Pomatoschistus microps, or euryhaline species like Gasterosteus aculeatus (Remane, 1958). The parasite's problem may be its adaptation to brackish water, even when its main host of the marine environment is absent. Consequently, two alternatives are possible: Dominance of parasites without complicated life-cycles, e.g. Thersitina gasterostei and, if complete cycles are performed, presence of generalists which do not prefer special hosts, e.g. Hysterothylacium sp. The large number of 18 digeneans found in the Schlei fjord combined with lower numbers of less specialized cestodes, nematodes and acanthocephalans or parasites without cycles seems to contradict this assumption.

Strategies which may help to adapt parasites to the brackish environment and its community can be compiled in 4 points:

1. Suspension of specificity. For instance, the copepod Thersitina gasterostei clearly prefers Gasterosteus aculeatus to Pungitius pungitius in marine and freshwater, but not in the brackish-water milieu of the Elbe and Eider rivers (Möller-Buchner, 1987). Podocotyle atomon was found especially in Littorina saxatilis in the North and Baltic Sea (MacKenzie \& Gibson, 1970; Zander et al., 1993). L. littorea which was also an important 1. host in the Schlei fjord was only very seldomly infested in the North or open Baltic Sea (Werding, 1969; Lauckner, 1984). Kidney cysts of Cryptocotyle concavum in its main host Pomatoschistus microps indicate a specialized coevolution (Zander et al., 1984) which was not found in P. minutus in the W Baltic (Zander et al., 1993) but was found in the Schlei fjord (Kreft, 1991). Kennedy (1975) interpreted the phenomenon of specificity 
breakdown as alteration of host suitability or as reduced immune defence under stress conditions.

2. Adaptation to hosts which are genuine brackish-water species. Pomatoschistus microps, Gammarus zaddachi, Idotea chelipes and Hydrobia stagnalis are genuine brackish-water species representing the host levels - fishes, benthic crustaceans and snails - in the Schlei fjord. These species were also conspicuous in that they harboured the most parasite species. This trend has already been recorded (Wendland, 1985; Kreft, 1991; Zander \& Westphal, 1991; Gollasch \& Zander, 1994). Contrarily, Pomatoschistus minutus, Gammarus locusta and Hydrobia ulvae were the most important hosts in the Lübeck Bight (W Baltic Sea with more than $10 \%$ salinity) (Zander et al., 1993, 1994; Strohbach pers. comm.). Gammarids which play this role in the Kiel Bight are Gammarus oceanicus and G. salinus (Voigt, 1991). Genuine brackish-water species such as the isopods Sphaeroma hookeri and S. rugicauda were, in addition to Jaera albifrons, the only benthic crustacean hosts in Missunde. This site of low salinity creates a characteristic section of the "species minimum" (Remane, 1958) in the Schlei fjord. The results of this investigation emphasize the adaptation of parasites to an extreme brackish-water milieu such as that in the Schlei fjord. The stress caused by brackish water may be heightened by a steep decrease and sudden fluctuations of salinity.

3. Extension of host spectra. The shrimp Crangon crangon as host for digenean parasites was first observed in the Schlei fjord (Podocotyle atomon: Gollasch \& Zander, 1995) and, thereafter, at other sites of the W Baltic (Microphallidae: Gollasch et al., 1996). Helminths have not been detected in the North Sea shrimp population where shrimps are of high commercial importance and have been intensively investigated (Tiews, 1954). The abundance of $C$. crangon in the shallow sand bottoms of the W Baltic Sea is generally as high as in the North Sea (Winkler, 1994) and, therefore, this species may be an ideal alternative host for diverse helminths in order to guarantee an accomplishment of their life-cycles. Another example is the microphallid digenean Maritrema subdolum which is a genuine brackish-water species that is able to extend its spectrum of final hosts to fish-eating birds by using fish as 3 . intermediate or transport hosts (Reimer, 1963).

4. Shortening of life-cycles. The genuine brackish-water parasites, Microphallus claviformis and Maritrema subdolum, developed a different strategy to reach their final bird hosts. Because their cercariae can encyst in their 1. hosts - snails (Deblock et al., 1961; Reimer, 1963) - as also found in this investigation, they can miss out the second-host level - the crustaceans. This strategy is widely distributed among microphallid digeneans and is most perfectly developed by Microphallus pygmaeus (Werding, 1969).

Therefore, the conditions for successful completion of the complicated helminth lifecycles seem to be present in the brackish milieu. Four of these life-cycles that disregard birds could be analysed quantitatively in this study. Gulls and terns from OeheSchleimünde, a nature reserve near the site of Olpenitz, harboured among other helminths adult Maritrema subdolum as well as Cryptocotyle concavum but not Microphallus claviformis (Kreft, 1991). The prevalence fluctuations of these three parasites and Podocotyle atomon in intermediate hosts were similar to those found at other sites (MacKenzie \& Gibson, 1970; Zander et al., 1984, 1994). The cycle of the fish digenean Podocotyle atomon is interrupted in Missunde due apparently only to the absence of the first host Littorina saxatilis or L. littorea. 


\section{Community analysis}

The parasite communities of the Schlei fjord were preliminarily influenced by the prevailing salinities at the two sites of Olpenitz and Missunde. According to Esch et al. (1988), the habitat quality can be judged by analysing which kind of helminth parasite cycles is present. Hence, eight species of Olpenitz and seven of Missunde were autogenic parasites which perform their whole cycles in the water: Twelve species of both sites were allogenic parasites which change from water to air, birds being their final hosts. These relations may indicate less favourable habitat conditions in Olpenitz and in Missunde than in undisturbed environments (Esch et al., 1988). The number of parasite species was, according to Remane's (1958) rule of species minimum, lower in Missunde than in Olpenitz, albeit without significance. Contrarily, the number of host-parasite combinations was significantly higher in Olpenitz. This may indicate that the existence of parasites may not depend on salinities in the same way as it does for hosts.

Additionally, the presence of core and secondary species in Olpenitz and their absence in Missunde were of high significance. Core species were rare in Olpenitz - two fish parasites and one crustacean parasite - but these were accompanied by seven secondary species. A similar situation was found in the Lübeck Bight with 10-16\% salinity where a guild of five goby species was infested by two secondary parasite species (Zander, 1993). In contrast to the Schlei fjord, the parasite communities of sticklebacks of the Elbe and Eider rivers showed no remarkable change of core species numbers at different salinities, including freshwater (Möller-Buchner, 1987).

Generally, prevalences were higher in Olpenitz than in Missunde. This seems to contradict the biocoenotic rule of Thienemann (1939) which claims increasing population densities and decreasing species numbers in extreme ecosystems. This situation is apparent in brackish waters at 5-8 \% salinity such as prevail in Missunde. Here the rare species dominated over the satellite species, whereas in Olpenitz a reverse situation was found. The only evidence for Thienemann's rule may be demonstrated by early cestode larvae infesting planktic copepods (Gollasch \& Zander, 1995), or plerocercoids of Proteocephalus percae infesting Pomatoschistus microps with higher intensities in Missunde than in Olpenitz (Kesting, 1992). These results may indicate that in Missunde not only salinity is responsible as stress factor but also pollution in general. This causes a deposition of mud on the bottom which influences especially the benthal zone of Missunde but to a lesser degree the pelagial zone where the cestodes complete their cycles.

Evidence of a better situation in the pelagial zone of Missunde may be given by planktic parasites such as Thersitina gasterostei, whose prevalence is one of the highest values of this site, or mero-planktic ones like Brachyphallus crenatus which is a satellite species at this site but a rare species in Olpenitz. Further evidence of drastical changes in the environmental conditions in the benthal zone of Missunde may be given by the infestation of Pomatoschistus microps by Cryptocotyle concavum which decreased strongly between 1978 (Zander et al., 1984) and 1991. This negative trend was intensified by the infestation of the 1. intermediate host of this parasite, Hydrobia spp., which was found in 1984 (Wendland, 1985) but not in 1985/1986 (Kreft, 1991) nor in the present investigation. Therefore, we may conclude that during the last 16 years a clear deterioration of ecological conditions has occurred. Such results are only available if long-term monitoring can be performed. 
Acknowledgement. We thank C. Berger for improving the English text.

\section{LITERATURE CITED}

Antholz, B., Meyer-Antholz, W. \& Zander, C. D., 1991. Feeding activities of two euryhaline smallsized fish in a western Baltic brackish fjord. - Helgoländer Meeresunters. 45, 287-300.

Deblock, S., Capron, A. \& Rosé, F., 1961. Contribution à l'étude des Microphallidae Travassos, 1920 (Trematoda). La genre Maritrema Nicoll, 1907, cycle évolutif de $M$. subdolum Jaegerskiöld 1909. - Parassitologia 3, 105-119.

Delling, D., 1975. Untersuchungen am Oligohalinikum der Schlei. I. Haddebyer und Selker Noor als Beispiele oligohaliner Lebensräume. - Kieler Meeresforsch. 31, 111-150.

Esch, G. W., Gibbons, J. W. \& Bourque, J. E., 1975. An analysis of the relationship between stress and parasitism. - Am. Midl. Nat. 93, 339-353.

Esch, G. W. Kennedy, C. R., Bush, A. O. \& Aho, J. M., 1988. Patterns in helminth communities in freshwater fish in Great Britain: alternative strategies for colonization. - Parasitology 96, 519-532.

Esch, G. W., Shostak, A. W., Marcogliese, D. J. \& Goater, T. M., 1990. Patterns and processes in helminth parasite communities: an overview. In: Parasite communities: patterns and processes. Ed. by G. W. Esch, A. O. Bush \& J. M. Aho. Chapman \& Hall, London, 1-19.

Gollasch, S., 1992. Populationsdynamik und Parasitenbefall von Bivalvia, benthischen und planktischen Crustacea in der Ostseeförde Schlei. Dipl-Arb., Univ. Hamburg, 175 pp.

Gollasch, S. \& Zander, C. D., 1995. Population dynamics and parasitation of planktonic and epibenthic crustaceans in the Baltic Schlei fjord. - Helgoländer Meeresunters. 49, 759-770.

Gollasch, S., Winkler, G., Strohbach, U. \& Zander, C. D., 1996. Digene Parasiten der Nordseegarnele, Crangon crangon (L., 1758), (Decapoda, Crustacea) aus der westlichen Ostsee. - Seevögel $17,3-4$.

Holmes, J. C. \& Price, P. W., 1986. Communities of parasites. In: Community ecology: Patterns and processes. Ed. by D. J. Anderson \& J. Kikkawa. Blackwell, Oxford, 187-213.

Kennedy, C. R., 1975. Ecological animal parasitology. Blackwell, Oxford, 163 pp.

Kesting, V., 1992. Untersuchungen zur Parasitenfauna von Kleinfischen und Schnecken der Ostseeförde Schlei. Dipl.-Arb., Univ. Hamburg, 183 pp.

Kreft, K. 1991. Befalls- und Populationsdynamik ausgewählter digener Trematoden und ihrer Wirte in der Schlei. Diss., Univ. Hamburg, 289 pp.

Lauckner, G., 1984. Impact of trematode parasitism on the fauna of a North Sea tidal flat. - Helgoländer Meeresunters. 37, 185-199.

MacKenzie, K. \& Gibson, D., 1970. Ecological studies of some parasites of plaice Pleuronectes platessa L. and flounder Platichthys flesus (L.). - Symp. Br. Soc. Parasitol. 8, 1-42.

Möller-Buchner, J., 1987. Untersuchungen zur Parasitenfauna drei- und neunstachliger Stichlinge (Gasterosteus aculeatus L. und Pungitius pungitius [L.]) aus Elbe, Eider und Schlei. Diss., Univ. Hamburg, $230 \mathrm{pp}$.

Nellen, W., 1967. Ökologie und Fauna (Makroevertebraten) der brackigen und hypertrophen Ostseeförde Schlei. - Arch. Hydrobiol. 63, 273-309.

Reimer, L. W., 1963. Zur Verbreitung von Adulti und Larvenstadien der Fam. Microphallidae Viana, 1924 (Trematoda, Digenea) in der mittleren Ostsee. - Z. Parasitkde 23, 253- 273.

Remane, A., 1958. Ökologie des Brackwassers. - Binnengewässer 12, 1-216.

Rheinheimer, G., 1970. Chemische, mikrobiologische und planktologische Untersuchungen der Schlei im Hinblick auf deren Abwasserbelastung. - Kieler Meeresforsch. 26, 105-216.

Rohde, K., 1982. Ecology of marine parasites. Univ. Queensland Press, St. Lucia, 245 pp.

Schmidt-Moser, R. \& Westphal, D., 1981. Interrelation between invertebrate plankton and larval fish development in the Schlei fjord, western Baltic. - Kieler Meeresforsch. (Sonderh.) 5, 202-210.

Schriever, G., 1974. Die sessile, hemisessile und vagile Hartbodenfauna der Schlei im ökologischen Vergleich. - Kieler Meeresforsch. 30, 80-90.

Thienemann, A., 1939. Grundzüge einer allgemeinen Ökologie. - Arch. Hydrobiol. 35, $267-285$.

Tiews, K., 1954. Die biologischen Grundlagen der Büsumer Garnelenfischerei. - Ber. dt. wiss. Kommn Meeresforsch. 13, 235-269. 
Voigt, M. O. C., 1991. Community structure of the helminth parasite fauna of gammarids (Crustacea: Amphipoda) in Kiel Bay, western Baltic Sea. - Meeresforsch. 33, 266- 274.

Wendland, W., 1985. Über das Auftreten digener Trematoden und ihrer Zwischenwirte Schnecken, Crustacea und Kleinfische in der Schlei unter besonderer Berücksichtigung der Microphalliden. Dipl.-Arb., Univ. Hamburg, 136 pp.

Werding, B., 1969. Morphologie, Entwicklung und Okologie digener Trematoden-Larven der Strandschnecke Littorina littorea. - Mar. Biol. 3, 306-333.

Winkler, G., 1994. Zur Populationsdynamik und Ernährungsbiologie von Crangon crangon L. (Crustacea; Crangonidae) in der Lübecker Bucht (Südwestliche Ostsee). Dipl.-Arb., Univ. Hamburg, $90 \mathrm{pp}$.

Zander, C. D., 1993. The biological indication of parasite life-cycles and communities from the Lübeck Bight, SW Baltic Sea. - Z. angew. Zool. 79, 377-389.

Zander, C. D. \& Westphal, D., 1991. Kleinfischparasiten der Ostseeförde Schlei und ihre Einbindung in die Nahrungskette. - Seevögel 12,4-8.

Zander, C. D. \& Westphal, D., 1992. Nahrungsbeziehungen von vier euryhalinen Kleinfischarten der Ostseeförde Schlei. - Zool. Jb. (Syst. Ökol. Geogr. Tiere) 119, 339-364.

Zander, C. D., Strohbach, U. \& Groenewold, S., 1993. The importance of gobies (Gobiidae, Teleostei) as hosts and transmitters of parasites in the SW Baltic. - Helgoländer Meeresunters. 47, 81-111.

Zander, C. D., Groenewold, S. \& Strohbach, U., 1994. Parasite transfer from crustacean to fish hosts in the Lübeck Bight, SW Baltic Sea. - Helgoländer Meeresunters. 48, 89- 105.

Zander, C. D., Kollra, H. G., Antholz, B., Meyer, W. \& Westphal, D., 1984. Small-sized euryhaline fish as intermediate hosts of the digenetic trematode Cryptocotyle concavum. - Helgoländer Meeresunters. $37,433-443$. 